\title{
ACHIEVEMENT OF THE HIGHEST LEVEL OF SAFETY AND HEALTH AT WORK AND THE SATISFACTION OF EMPLOYEES IN THE TEXTILE INDUSTRY
}

\author{
Snežana Urošević \\ University of Belgrade, Technical Faculty in Bor, Department of Management \\ Vojske Jugoslavije, Bor, Serbia \\ e-mail: surosevic@tf.bor.ac.rs
}

\begin{abstract}
Safety and health at work involves the exercise of such working conditions that take certain measures and activities in order to protect the life and health of employees. The interest of society, of all stakeholders and every individual is to achieve the highest level of safety and health at work, to unwanted consequences such as injuries, occupational diseases and diseases related to work are reduced to a minimum, and to create the conditions work in which employees have a sense of satisfaction in the performance of their professional duties. Textile industry is a sector with higher risk, because the plants of textile industry prevailing unfavorable microclimate conditions: high air temperature and high humidity, and often insufficient illumination of rooms and increased noise. The whole line of production in the textile industry, there is a risk of injury, the most common with mechanical force, or gaining burns from heat or chemicals. All of these factors are present in the process of production and processing of textiles and the same may affect the incidence of occupational diseases of workers, absenteeism, reduction of their working capacity and productivity. With the progress of the textile industry production increases in the number of hazardous and harmful substances that may pose a potential danger to the employee in this branch of the economy as well as the harmful impact on the environment. Therefore, it is important to give special attention to these problems.
\end{abstract}

Keywords: textile industry, health, safety, like conditions, employee satisfaction.

\section{INTRODUCTION}

Health, safety and general working conditions are very important field of research and the operation of human resource management. Knowledge about the factors that affect the health and safety of employees is crucial and therefore attitudes of employees on these issues must be taken into account when planning the program for the protection of the health and safety of employees [1]. Safety and Health at Work means organizing such working conditions that are largely reduce injuries at work and professional diseases and diseases related to work. They create the prerequisite for full physical, mental and social well-being of employees, which is required by the provisions of the Law on Safety and Health at Work.

System safety and health at work means mutual influence of different factors such as legislation, inspection, insurance, technical knowledge and solutions, occupational health services, health, information, education, research and others. Problems related to diseases and accidents at work seriously jeopardize the working potential of employees and therefore represent one of the important topics of human resource management. They simultaneously affect the costs of the organization, motivation and satisfaction of employees, but they also have an ethical dimension, which stems from social responsibility. All this has an impact on the survival and success of the organization in a competitive market [10]. 


\section{ART'TE

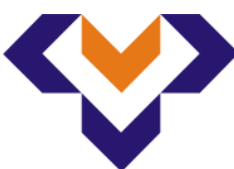 \\ Ipplied Resseirlohes in Technics, Technologies and Bductation \\ Journal of the Faculty of Technics and Technologies, Trakia University \\ https://sites.google.com/a/trakia-uni.bg/artte/}

The employer is obliged to organize the work of ensuring the protection of life and health of employees, in accordance with the law and other regulations [2]. Management organization bears full responsibility for creating safe and respectful working conditions for the preservation of physical and mental health of employees.

Working conditions in the global textile industry are very poor because employees in most developing countries have no labor rights established by law. Many employees in companies of the textile industry in the world work in unacceptable conditions, which negatively affects the health and safety of workers. Workers are exposed to many dangers and hazards, and the most toxic substances used in textile-treatment preparations of chlorine, organic solvents, aniline dyes, various acids and salts of chromium, copper and zinc, and organic dust and noise impact (often over $95 \mathrm{~dB}$ ). Eye strain, fatigue and frequent occupational injuries occur because of poor ergonomic conditions. Also, reproductive health, especially women, may be affected if employees are exposed to chemicals, high temperatures working environment, noise and other harmful factors [15].

The technological processes of textile industry used a number of different groups of chemicals primarily different types of organic dyes, solvents, bleach, heavy metals and the like. Toxic effects of heavy metals on human health are well known today, it is necessary to control their presence during the production and processing of textile materials [9].

\section{ROLE OF MANAGEMENT HUMAN RESOURCES PRESERVATION OF HEALTH AND SAFETY WORK IN ORGANIZATIONS}

The question of protecting the health and safety of employees at work in organizations is realized through the establishment, control, operation and maintenance of the system of health and safety at work, whose primary role is the implementation of human resource management. The same can be seen as a subsystem of the quality system of the organization.

In modern organizations, health promotion has a very important role, given that the success of the organization depends on whether she has a well-qualified, motivated and healthy employees are ready to face new challenges.

There are numerous positive effects for the performance of the organization resulting from the successful health promotion in the workplace. Here primarily thoughts on:

- increased productivity,

- reducing absenteeism,

- reducing the number of civil cases due to accidents and ill health caused by mistake,

- better selection of staff and fewer personnel changes,

- improved relationships between employees,

- lower level of professional stress,

- improving the working environment,

- improving the image of the company.

Preserving the high level of health and safety at work is an important human aspect, which shows the ethical and social development level of the organization. Increasing the level of safety and health at work, the creation of favorable conditions of work and labor relations, optimization of working processes affect the achievement of a high degree of employee satisfaction, achieving general welfare of employees and achieving organizational objectives [4].

The obligation of the management of the organization is to provide conditions for safe and healthy work employees. They are required by law to systematically monitor and eliminate any potential hazards in the workplace. For an organization to function effectively in terms of security and protection of health workers, it is important that employees are informed about

IRTIIE Vol. 4, No. 3, 2016 ISSN 1314-8788 (print), ISSN 1314-8796 (online), doi: 10.15547/artte.2016.03.002 


\section{ARTTIE $Y$}

Ipplied Resseirlohes in Technics, Technologies and Bductation

Journal of the Faculty of Technics and Technologies, Trakia University https://sites.google.com/a/trakia-uni.bg/artte/

the dangers that exist in all of their organization and that they are aware of the protective measures and first aid if a hazard occurs.

\section{EFFECT OF SPECIFICS OF TEXTILE PRODUCTION AND CONDITIONS OF WORK ENVIRONMENT HEALTH AND SAFETY OF EMPLOYEES}

There are many factors in the working environment may affect human health. Under the working environment factors include all material factors that workers receive work activity. Physical factors include physical and technical conditions of the working environment. Therefore, they can be grouped into two basic groups.

The first group of these factors make up the physical factors of the working environment, which, in a sense, represent the environmental conditions. These include: [5]

- air and microclimate (temperature, humidity, air circulation),

- lighting,

- noise and vibration, and

- radiation.

While the second group of factors are those factors that arise from the operation of machines, use tools and effects of electricity on employees.

Currently or permanently functioning of those influential factors, causes harmful effects on humans, depending on the intensity of this impact and the number of circumstances which should primarily be counted: the strength of the fact, resistance and protective measures. The most widespread are the consequences: injuries and accidents at work and occupational diseases.

Textile and clothing sector in Europe has changed over the years as a result of technological developments and changes in economic conditions and increasing competitive pressure [6] which caused the company restructuring, modernization and adaptation to technological change. Development of technical and industrial products, influenced also on employment in the textile sector, where there has been a change in patterns of employment (eg. The conclusion of sub-contracts), as a result of the applied techniques, there has been a change in the hazards and risks which today workers are exposed in the process of industrial production [13].

Textile industry is technically and technologically very demanding. Manufacture of textiles basically requires several stages of machining, such as spinning, weaving, knitting and garment production, and chemical processing such as dyeing, printing and finishing of textile materials and finishing garments.

Most of the processes and products of the textile industry, which are part of modern life have a negative impact on the environment because of the presence of a number of chemical substances used in the technological processing of materials. To meet these demands, it is necessary to employ a qualified skilled workforce which possesses the necessary competence [7], knowledge and skills and is willing to answer all the challenges that are posed by the presence of large fluctuations and rapid changes in the market $[8,3]$.

In areas of the textile industry prevailing unfavorable microclimate conditions: High air temperature (over $30^{\circ} \mathrm{C}$ ) and high humidity $(90 \%)$, and often insufficient brightness of the rooms. On the whole production line from design to the production of yarn fabric, there is a risk of injury, the most common mechanical force, or gaining burns from heat or chemicals. All of these factors are present in the process of production and processing of textiles and may affect the incidence of occupational diseases of employees, absenteeism, reduction of their working capacity and productivity. It is for the foregoing reasons, the textile industry is assessed as a sector with an increased risk [16].

IRTIIE Vol. 4, No. 3, 2016 ISSN 1314-8788 (print), ISSN 1314-8796 (online), doi: 10.15547/artte.2016.03.002 


\section{ARTTIE $Y$}

Ipplied Researr'hes in Technics, Technologies and Bdurition

Journal of the Faculty of Technics and Technologies, Trakia University https://sites.google.com/a/trakia-uni.bg/artte/

Many employees in companies of the textile industry in the world work in unacceptable conditions, which negatively affects the health and safety of workers. It is known that a number of factors that threaten the man in the workplace and outside it - physical factors: microclimate (temperature, humidity and air velocity), lighting, noise, vibration, and radiation and factors arising from the operation of machinery, equipment, use of tools and the hazardous effects of electric current, chemical and biologically active agents.

Textile industry consists of a large number of processes which are required for the conversion of fibers into the fabric or clothing. The main safety and health problem in the textile industry can be divided into:

- leaving the textile dust,

- exposure to chemicals,

- exposure to loud noise,

- ergonomic problems.

Employees in direct production working on processing and spinning of cotton are exposed to significant amounts of cotton dust. They are also exposed to pesticides from soil particles. Exposure to cotton dust and other particles can cause severe respiratory diseases textile workers. The disease is caused by cotton dust is still described in the seventeenth century, but only the last 40 years has become a global problem in the textile industry.

Workers in the textile industry are exposed to a large number of chemicals, especially those engaged in dyeing, printing and finishing of textiles. In various production processes use chemicals based on benzidine, organic solvents and chemicals, which are used in anticrease finishing emit formaldehyde, protect against flammability used organophosphorus compounds or organobromine then also used antimicrobials in various textile operations. Studies have revealed the relationship between exposure to formaldehyde and lung cancer and brain, as well as leukaemia. Skin damage resulting activity of harmful agents in the working environment represents a group of the most common occupational diseases in the textile industry. Representation of professional dermatoses caused by the activity of chemicals in relation to other occupational diseases, ranges from $20-70 \%$.

High levels of noise exposed workers were engaged in the textile industry in developing countries. Exposure to noise over a long period can damage the eardrum and can cause hearing loss. Other problems such as fatigue, absenteeism, agitation, anxiety, reduction of work capacity and efficiency, changes in heart rate and blood pressure, and sleep disturbances are also observed in the continuous exposure to noise. A lack of effective maintenance of machinery is one of the main reasons for the increase noise levels in most of the manufacturing units of the textile industry. Although noise exposure in textile factories causing serious health consequences, often ignored because its effects are not immediately visible.

Ergonomic problems were observed in most of the work units engaged in activities linked to the production of textiles and clothing. Employees in textile plants are unsafe and unhealthy working environment because they face big problems: inadequate furniture, inadequate ventilation and lighting, as well as the lack of effective security measures in case of emergency. Workers in such production units are at risk of developing a variety of occupational diseases [12].

On the basis of statistical sources can be pointed out that the sector of the textile industry in recent years, in the developed countries of the world, stands 3-4\% of total investment in new resources to work in the production process. In the nineties of the twentieth century, textiles became an important market for top industry such as robotics, electronics, computer science, which is still influenced to a significant increase in the productivity of companies in the industry, and literally to the technical revolution. All this affected the increase in the annual production of fabrics. Speed, open end spinning "loom, new looms in the air and water jets and missiles, increased by 10 times compared to the traditional way of spinning looms with

IRTIIE Vol. 4, No. 3, 2016 ISSN 1314-8788 (print), ISSN 1314-8796 (online), doi: 10.15547/artte.2016.03.002 


\section{ARTTIE $Y$}

Ipplied Resseirlohes in Technics, Technologies and Bductation

Journal of the Faculty of Technics and Technologies, Trakia University https://sites.google.com/a/trakia-uni.bg/artte/

shuttle looms. Modernization of the equipment, in addition to increasing the quality of products has led to changes in the technical aspect of production, starting with reducing the number of stages of production, to process automation and transportation of products to the warehouse with the entire production line, as well as to the use of multipurpose machines. Microprocessors are installed in all types of machinery and computerized production, optimize the production of drawings, fabric and shape. Modern fashion industry is constantly seeking new products to encourage research and innovation in this sector and encourage the discovery of new materials better characteristics. More and more weight making fibers of smaller thickness, acting on the molecules of which it is composed. [14] Textiles, textile products, modern textile industry as a combined material, expands the field of work of the textile industry, connecting the construction industry (concrete firmness) and medicine, shall be biodegradable tissue in the human body - eg. textile reinforcement in plastic surgery [16]. These changes in the production process in the textile industry development, however, did not significantly affect the reduction of workplace injuries and occupational diseases of employees in the industry. Each process of textile production was traditional or contemporary higher or lower degree contains risks to the safety and health of employees affected by the emergence of a professional team conquer technique and diseases related to work. What can be noted is that in recent years greatly increased the activity of their managers of human resources in safeguarding the safety and health of workers and the active participation of the management of health promotion at work in this segment of industrial production.

Environmental pollution caused by excessive creation of textile waste as well as high consumption of natural resources, oil and other raw materials used in the further production of textile materials, require finding possibilities for their reuse. The laws and environmental standards stipulate strict criteria for processes in the textile industry in accordance with the laws of the European Union. Also, the textile industry emits a wide range of pollutants at all stages of processing fibers into textile material. All these substances and hazards in the working environment and working environment, be sure to exposed workers employed in this sector.

\section{CONCLUSION}

Safety and health at work involves the realization of the working conditions in which they undertake certain measures and activities in order to protect the life and health of employees. The interest of society, of all stakeholders and every individual is to achieve the highest level of safety and health at work, to unwanted consequences such as injuries, occupational diseases and diseases related to work are reduced to a minimum, and to create the conditions work in which employees have a sense of satisfaction in the performance of their professional duties. For the realization of this aim, a systematic approach to preventive action and connect all entities who are holders of certain obligations and activities. The management system of health and safety at work, as part of the management of the organization, has the task of developing and implementing a policy of health and safety and risk management of health and safety at work. With the progress of industrial production increases in the number of hazardous and harmful substances that may pose a potential danger to the employee and his environment. It is therefore very important that these problems special attention.

Safety and health measures play an important role in any industry, including the textile. It is important that employees in the textile industry should be aware of different occupational risks. At the same time, it is essential that management take the necessary steps to protect workers from potential dangerous situations and raise awareness of the health problems in the organization and their economic importance. Bearing in mind that the concern about the employee one of the most important aspects of socially responsible business organization,

IRTIIE Vol. 4, No. 3, 2016 ISSN 1314-8788 (print), ISSN 1314-8796 (online), doi: 10.15547/artte.2016.03.002 


\section{ARTTIE $Y$}

Ipplied Resseirlohes in Technics, Technologies and Bductation

Journal of the Faculty of Technics and Technologies, Trakia University https://sites.google.com/a/trakia-uni.bg/artte/

motivation of employees, their satisfaction, mid-career training and development are both personal as well as the success of the organization. One of the factors that greatly affect the satisfaction of employees considered is the safety and health of workers at work, which is closely related to the conditions of the working environment. Download all measures in order to eliminate the risk of possible injuries and occupational diseases is the main activity of management of modern organizations.

\section{ACKNOWLEDGEMENTS}

I thank the Ministry of Education and Science of the Republic of Serbia for financing the project TR 34020, which is derived from this work.

\section{REFERENCES}

[1] Bogićević Milikić, B. (2006). Menadžment ljudskih resursa, Ekonomski fakultet, Univerzitet u Beogradu, Beograd.

[2] Jovanović P. (2012). Radno pravo, Pravni fakultet, Univerzitet u Novom Sadu. Novi Sad.

[3] Jovanović, R. (2005). Tekstilna industrija Srbije. Beograd: G17 Institut.

[4] Logasakthi K., \& Rajagopal K. (2013). A study of employee healt, safety and welfare measures of hemical industry in the view of salem region, International Journal of Research in Business Management (IJRBM), Vol. 1, No 1, 1-10.

[5] Martinović M., \& Tanasković Z. (2014). Menadžment ljudskih resursa, Užice.

[6] Martinuzzi A., Kudlak R., Faber C., \&Wiman A. (2011). CSR Activities and Impacts of the Textile Sector, Research Institute for Managing Sustainability (RIMAS) Vienna University of Economics and Business.

[7] Poznanović, S., \& Muratović, Š. (2014). Significance of company management in the development of textile industry staff, 4rd International Conference "Economics and Management - Based on New Technologies", EmoNT 2014. 12-12. Jun 2014. pp. 289296. Vrnjačka Banja.

[8] UNEP (1994). The Textile Industry and the Environment. Retrieved 22.01.2014. from http://www.faculty.ait.ac.th/visu/Data/Publications/Chapters\%20\&\%20books/The\%20Tex tile\%20Industry\%20and\%20the\%20environment.pdf.

[9] Urošević S., Đorđević D., (2014). Textile Dye As Potential Dangerous Polluters, International scientific conference, International scientific conference, "Sustainable Economy And The Environment", Beograd, Serbia, 23-25.april 2014, Book of abstracts, pp. 132.

[10] Urošević Snežana, Stefanović V., Đorđević D., (2015), Menadžment sistem zdravlja i bezbednosti na radu u tekstilnoj industriji, Tekstilna industrija, LXII- No 4, pp. 45-53.

[11] http://osha.europa.eu/e-činjenice

[12] http://www.fibre2fashion.com/industry-article/3/297/safety-and-health-issues-in-thetextile-industry1.asp.

[13] http://www.hse.gov.uk/textiles/index.htm.

[14] https://borefor.wordpress.com/2011/10/09/inovacije-u-industriji-tekstila/.

[15] https://laboureconomics.wordpress.com/2013/04/30/working-conditions-in-the-globalfashion-industry.

[16] https://osha.europa.eu/en/tools-and-publications/publications/e-facts/efact30. 